\title{
Review of follow-up of clinical success of implant-supported complete dental prostheses
}

\author{
Revisão do sucesso clínico longitudinal dos implantes pilares de prótese total
}

Gustavo Diniz GRECO'

Amanda Beatriz Dahdah Aniceto de FREITAS ${ }^{1}$

Cláudia Silami de MAGALHÃES'

Allyson Nogueira MOREIRA'

\section{ABSTRACT}

\section{Objective}

The aim of this study was to assess the clinical success rate of implant-supported complete dental prostheses, which are being used as a feasible alternative in planning of oral rehabilitation. Over the years, the two-stage surgical protocol has increasingly been replaced by immediate loading procedures, especially in the mandibular anterior region in cases of rehabilitation of completely edentulous patients. This procedure has become feasible due to the high success rate of the technique with very satisfactory results.

\section{Methods}

By means of a literature review focused on published articles with clinical follow-up between 8 and 15 years.

\section{Results}

Implants placed in the mandible had higher success rates than those inserted in the maxilla. Cases with longer follow-up periods, 15 years, showed higher success rates in comparison with follow-up periods of 8 and 10 years.

\section{Conclusion}

Success rates of implant-supported complete dental prostheses are very high.

Indexing terms: Complete dental prostheses. Dental implantation. Osseointegration

\section{RESUMO}

\section{Objetivo}

Avaliar o índice de sucesso clínico dos implantes pilares de próteses totais implantossuportadas. As próteses implantossuportadas vêm sendo utilizadas como uma alternativa viável ao planejamento de reabilitação oral. O protocolo de dois estágios cirúrgicos, ao passar dos anos, vem sendo cada vez mais substituídos pelos procedimentos de carga imediata, principalmente na região anterior inferior, nos casos de reabilitação de pacientes totalmente desdentados. Tal procedimento torna-se viável devido ao alto índice de sucesso da técnica com resultados bastante satisfatórios.

\section{Métodos}

Por meio de uma revisão de literatura focada em trabalhos publicados com acompanhamento clínico entre 8 e 15 anos.

\section{Resultados}

Os implantes instalados em mandíbula apresentaram índices de sucesso maiores que os instalados em maxila. Os casos com acompanhamento mais longos, com 15 anos, apresentaram índices de sucesso maiores do que quando comparados aos acompanhamentos de 8 e 10 anos.

\section{Conclusão}

O índice de sucesso dos implantes pilares de prótese total é bastante alto.

Termos de indexação: Prótese total. Implantação dentária. Osseointegração.

\footnotetext{
${ }^{1}$ Federal University of Minas Gerais, Dental School. Av. Antonio Carlos, 6627, Pampulha, 31270-901, Belo Horizonte, MG, Brasil. Correspondência para / Correspondence to: GD GRECO. E-mail: <gustavodgreco@yahoo.com.br>.
} 


\section{INTRODUCTION}

Planning of cases of oral rehabilitation in completely or partially edentulous patients has undergone drastic changes as from the mid-1960s, with the introduction of the concepts of osseointegration. These patients are now able to avail themselves of the possibility of being rehabilitated with complete or partial implant supported dental prostheses.

The clinical protocol created by Brånemark has made it possible to insert implant-supported dentures after two surgical procedures, with time intervals that range between three and six months, which makes it feasible for the period of osseointegration to occur ${ }^{1-8}$.

In the first surgical stage, the implants are correctly positioned in the bone tissue, and remain "submersed" under the mucosa, so that healing may take place without compromising factors, such as stress, mobility, infection, trauma and apical migration of the epithelial tissue, in order for osseointegration to occur. In the second surgical stage, implants are once again exposed and prepared for placement of the dental prosthesis. Over the last few years, there has been an increasing body of evidence of successful treatment with osseointegrated implants in a surgical protocol involving only one stage, with dental prosthesis placement in a maximum time of up to 72 hours after the surgical act.

Irrespective of the protocol of choice for rehabilitating edentulous patients, they would be submitted to at least one surgical intervention. Moreover, various clinical sessions are required for denture fabrication and adjustments, until the patient is able to make use of his/her fixed dental prosthesis. Nowadays, the cost of this treatment is still a long way from the financial reality of the Brazilian population. Therefore, the clinical success of this work of oral rehabilitation is very important in the decision of the patient who is a candidate for submission to this treatment.

The purpose of this study was to make an approach, by means of secondary data, to longitudinal studies, in order to analyze the clinical success of both maxillary and mandibular complete implant-supported dental prostheses, in function for a period between eight and fifteen years, seeking a scientifically based evaluation of this type of oral rehabilitation.

\section{METHODS}

In this study, the methodology used was the active search for information in the databases of Bireme, Medline,
Lilacs, Pubmed, SciELO, Google Academic, Cochrane Library, $E B D$ and Oral Health Specialist Library. An endeavor was made to conduct a bibliographic research about the clinical success rate of implants that supported complete dental prostheses. With the purpose of delimiting the aim of the study and field of investigation for the reality one intended to study, the option was to select only productions in the form of articles published in indexed periodicals, considering the year 1970 as the beginning of the period for this survey. This option was taken due to the fact that osseointegration began to be described as from the mid-1960s. The descriptors used for the search for scientific articles about complete implantsupported dental prostheses were as follows: implant, complete dental prostheses and osseointegration

The descriptors were used with truncation symbols, with searches for words in all the databases. A total number of 1743 studies were found. Of these, based on the information in their titles, 32 were selected for evaluation of the abstracts. After pre-selection of these abstracts, 16 studies were fully analyzed, and only 10 of these were selected for inclusion in the review. The criteria for the inclusion of scientific articles were as follows:

- longitudinal clinical studies;

- minimum follow-up period of eight and maximum of 15 years;

- rehabilitation of complete implant-supported dental prostheses;

- complete articles published in periodicals.

Selection was based on conformity of the limits of the subject with the objectives of this study. Therefore, in spite of appearing in the result of the search, studies that did not deal with the subject from the point of interest of this study were not considered for inclusion.

\section{RESULTS}

Among the 16 studies selected, 6 were excluded because they dealt with clinical studies with a follow-up period of less than 8 years ${ }^{9-14}$.

The articles included in this study are listed in Table 1 , in which we may observe the number of implants used, success rates in the maxilla and mandible, and period of clinical follow-up.

Longitudinal clinical follow-up allows for an evaluation of the clinical success rate of implants that support complete dentures. A uniformity is noted in the values of success rates of rehabilitations in the mandible, with the lowest percentage value found being $90 \%{ }^{18}$ with a 
Table 1. Articles included in the review.

\begin{tabular}{|c|c|c|c|c|c|}
\hline References & n. of implants & Success in maxilla \% & Success in mandible \% & Period of study in years & Complete denture $\%$ \\
\hline Adell et al. ${ }^{5}$ & 4,636 & 92 & 99 & 15 & 100 \\
\hline Adell et al. ${ }^{3}$ & 2,768 & 89 & 100 & 15 & 100 \\
\hline Bränemark et al. ${ }^{15}$ & 882 & 79 & 91 & 10 & 100 \\
\hline Kirsch \& Ackerman ${ }^{16}$ & 538 & 97 & 99 & 10 & 100 \\
\hline Albrektsson et al. ${ }^{7}$ & 8,139 & 85 & 99 & 8 & 100 \\
\hline Albrektsson ${ }^{8}$ & 1,269 & 89 & 93 & 8 & 100 \\
\hline Hass et al. ${ }^{18}$ & 1,920 & 38 & 90 & 8 & 100 \\
\hline Buser et al. ${ }^{19}$ & 1,180 & 87 & 95 & 8 & 100 \\
\hline Total/mean & 26,718 & 83.7 & 96 & 10.7 & 100 \\
\hline
\end{tabular}

follow-up period of 8 years and $100 \%{ }^{3-5}$, with a follow-up period of 15 years in both cases. The mean for all the followup periods for implant-supported dental prostheses inserted in the mandible was $96 \%$. Whereas, for the success rate in the maxilla, Hass $^{18}$ presented rather divergent percentage values, finding a success rate of $38 \%$, while the other nine studies showed mean values ranging between 79 and $97 \%$, which provides a total mean value of $83.7 \%$ clinical success in a period longer than eight years. The total number of implants inserted was 26,718 , totaling approximately 4,500 implant-supported complete dental prostheses.

When one analyzes the success rate of mandibular dental prostheses, in relation to the follow-up period, it is possible to observe a mean of $94.25 \%$ for the studies with a follow-up period of 8 years, $94.66 \%$ for those with a follow-up period of 10 years, and $99.66 \%$ for those with a follow-up period of 15 years. When one analyzes the success rate of maxillary dental prostheses, in relation to the follow-up period, one observes a mean of $74.75 \%$ for the period of 8 years, $89 \%$ for the period of 10 years, and $90.33 \%$ for the period of 15 years.

When the total number of implants inserted to support complete dentures was analyzed, it was possible to observe that of the $26, .718$ implants placed, 2,504 $(9.37 \%)$ were lost. This percentage of loss, according to the reports of the studies selected, occurred in larger numbers between the two surgical time intervals, that is to say, before the dental prosthesis were fitted.

\section{DISCUSSION}

Oral rehabilitation of completely edentulous patients by means of therapy with commercially pure titanium dental implants "ad modum" Brånemark, revolutionized and expanded the horizons in dentistry. Over 2000 scientific publications over the last 35 years, confirm the high success rate achieved by this type of treatment ${ }^{20}$. From this perspective, any deviation from the protocol established by Brånemark would be equivalent to introducing risk factors, especially for obtaining osseointegration. However, in spite of the high success rates and predictability of the two-stage protocol, many patients are reluctant to be submitted to this type of treatment, because the procedure demands the use of a transitional removable dental prosthesis, or in many cases, no denture for a long period after the first stage, which results in serious functional and psychosocial problems for patients'.

Before introduction of the Brånemark protocol, the concept of immediate load on implants was widespread ${ }^{21}$. The re-introduction of this concept would have to oppose the absolute paradigms for obtaining osseointegration, particularly the fact that implants must remain submersed during the healing period. There is high predictability of implants attaining osseointegration when inserted in the anterior region of the mandible, even when exposed to the oral cavity, and provided good oral hygiene is maintained ${ }^{22-26}$. The indications of this technique for the completely or partially edentulous mandible and maxilla have been extended, based on studies that have demonstrated their predictability, with a reduction in the number of surgical acts to which patients have to be submitted, and reduction in time between the placement of implants and the dental prosthesis ${ }^{27}$. The second paradigm would be the fact that should the implants be subjected to occlusal load before they attain osseointegration, the latter would be lost ${ }^{27}$. The quantity of micromovements that may be tolerated, without there being interruption of bone formation around the implant, and that a bond between the bone and a 
metal would occur in the presence of micromovements and not in the presence of macromovements, are unknown ${ }^{28}$. Micromovements exceeding 100 micrometers in smooth surfaced implants must be avoided, because a greater extent of movement may lead to the formation of fibrous tissue around the implant. In view of this, one may perceive that the problem is not the presence of micromovement, but rather one of how to control it ${ }^{29}$

The results presented in this review indicate that the success rates of implant-supported complete dental prostheses are very high, with the highest values being observed in the older studies, with clinical follow-up of 15 years. This may be explained by the almost exclusive use of two-stage surgical protocols. Whereas, in some studies with follow-up of 10 years, and in the majority of those with follow-up of 8 years, it was possible to observe the introduction in their methodologies, of implant-supported rehabilitations with one-stage surgical protocols. That is to say, dentures with immediate loading, including in the maxilla, which may be one of the reasons for this small drop in the success rates.

The Bränemark protocol determines that as abutments, the implant-supported complete denture must have implants located in the anterior region of the maxilla, that is to say, in the region of the mento. This determination is due to the anatomic limitations generated by the inferior alveolar nerve in the majority of edentulous patients, and particularly by the bone quality found in this area. In the metal region, the bone tissue presents a large quantity of cortical bone, which is able to provide a most interesting initial stability of the insertion of the prosthesis, whether it is mediate, or immediate.

Whereas, in the maxillary regions, particularly in the posterior portion, there is bone tissue with a great deal of medullary and little cortical structure, which makes it difficult to attain the initial stability of these implants ${ }^{15}$.

With regard to the period in which the implants were lost, it was observed that a significant portion of those lost were diagnosed in the interval between the first and second surgical act. In the first six months of clinical follow-up after insertion of the dental prostheses, the

\section{REFERENCES}

1. Brånemark P-I, Hansson B-0, Adell R, Breine U, Lindstrom J, Hallen 0 , et al. Osseointegrated implants in the treatment of the edentulous jaw: experience from a 10-year period. Scand J Plast Reconstr Surg Hand Surg. 1977;16:1-132. percentage of loss diminished significantly, particularly in cases in which the patient presented an edentulous antagonist arch rehabilitated by means of a removable complete or mucosupported dental prosthesis.

Another factor that may influence the results of this type of implant-supported rehabilitation is periimplant bone loss, which normally occurs in the first year of function, that is to say, after fabrication of the dental prosthesis. There is an interesting relationship with regard to the quality of surface treatment applied to this implant, seeing that the smooth surface of implants lead to a more accentuated peri-implant bone loss. ${ }^{30}$. However, in this review, it was clear that smooth surfaced implants presented a very high success rate, seeing that in the majority of studies consulted ${ }^{3-5,7-8}$, smooth surfaced implants were used, demonstrating that in the long term, this type of rehabilitation has a most favorable prognosis.

This study shows that the success of implantsupported complete dental prostheses may attain high success rates, provided the techniques and the protocols for each case are respected.

\section{CONCLUSION}

The implant-supported complete dental prosthesis presents a high success rate, with a growing body of scientific evidence, and can be indicated for the treatment of completely edentulous patients. Whereas, implantsupported complete mandibular dental prostheses presented higher levels of clinical success in comparison with the maxillary type, however, both were shown to have high functional stability, for a period of up to 15 years.

\section{Collaborators}

GD GRECO and ABDA FREITAS were responsible for the design and development of the study methodology, involving the search, selection, evaluation of the articles, and writing the article. AN MOREIRA and CS MAGALHÃES participated in the design of the methodology and writing the article.

2. Brånemark P-I, Breine U, Adell R, Hansson 0, Lindstrom J, Ohlsson A. Intra-osseous anchorage of dental prostheses. I. Experimental studies. Scand J Plast Reconstr Surg Hand Surg. 1969;3(2):81-100.

3. Adell R, Lekholm U, Rockler B, Brånemark P-I. A 15 year study of osseointegrated implants in the treatment of edentulous jaws. Int J Oral Surg. 1981;10(6):387-416. doi: 10.1016/S03009785(81)80077-4 
4. Adell R. Clinical results of osseointegrated implants supporting fixed prostheses in edentulous jaws. J Prosthet Dent. 1983;50(2):251-4. doi: 10.1016/0022-3913(83)90026-4

5. Adell R, Eriksson B, Lekholm U, Brånemark P-I, Jemt T. A long-term follow up study of osseointegrated implants in the treatment of totally edentulous jaws. Int J Oral Maxillofac Surg. 1990;5(4):347-59.

6. Albrektsson $T$, Zarb G, Worthington P, Eriksson AR. The longterm efficacy of currently used dental implants: A review and proposed criteria of success. Int J Oral Maxillofac Implants. 1986;1(1):11-25.

7. Albrektsson T, Dahl E, Enbom L, Engevall S, Engquist B, Eriksson $A R$, et al. Osseointegrated oral implants: a Swedish multicenter study of 8139 consecutively inserted Nobelpharma implants. J Periodontol. 1988;59(5):287-96. doi: 10.1902/ jop.1988.59.5.287

8. Albrektsson T. A multicenter report on osseointegrated oral implants. J Prosthet Dent. 1988;60(1):75-84. doi: 10.1016/00223913(88)90355-1

9. Patrick D, Zosky I, Lubar R, Buchs A. The longitudinal clinical efficacy of core-vent dental implants: a five years report. J Oral Implants. 1989;15(2):95-103.

10. Jemt T. Fixed implant supported prostheses in edentulous maxillae: a 5 year follow-up report. Clin Oral Implants Res. 1994;5(3):142-7. doi: 10.1034/j.1600-0501.1994.050304.x

11. Fugazzotto $P$, Gulbransen $H$, Wheeler S, Lindsay J. The use of IMZ osseointegrated implants in partially and completely edentulous patients: success and failure rates of 2023 implant cylinders up to 60+ months in function. Int J Oral Maxillofac Implants. 1993;8(6):635-40.

12. Babbush C, Shimura M. Five year statistical and clinical observations with the IMZ two stage osseointegrated implant system. Int J Oral Maxillofac Implants. 1993;8(3):245-53.

13. Saadoun A, LeGall M. Clinical results and guidelines on SteriOss endosseous implants. Int J Periodontics Restorative Dent. 1992;12(6):487-99. doi: 10.11607/prd.00.0035

14. Lill W, Thornton B, Reichsthaler J, Schneider B. Statistical analyses on the success potential of osseointegrated implants: a retrospective single dimension statistical analysis. J Prosthet Dent. 1993;69(1):176-85. doi: 10.1016/0022-3913(93)90138-E

15. Brånemark P-I, Svensson B, van Steenberghe D. Ten-year survival rates of fixed prostheses on four or six implants ad modum Branemark in full edentulism. Clin Oral Implants Res. 1995;6(4):227-31. doi: 10.1034/j.1600-0501.1995.060405.x

16. Kirsch A, Ackermann K. The IMZ osseointegrated implant system. Dent Clin North Am. 1989;33:733-91.

17. Ferrigno N, Laureti M, Fanali S, Grippaudo G. A long-term follow-up study of non-submerged ITI implants in the treatment of totally edentulous jaws. Clin Oral Impl Res. 2002;13(3):26073. doi: 10.1034/j.1600-0501.2002.130305.x
18. Haas R, Mensdorff-Pouilly N, Mailath G, Watzek G. Survival of 1920 IMZ implants followed for up to 100 months. Int J Oral Maxillofac Implants. 1996;11(5):581-8.

19. Buser D, Mericske-Stern R, Bernard J, Behneke A, Behneke $N$, Belser $U$, et al. Long-term evaluation of nonsubmerged IT1 implants. Clin Oral Implants Res. 1997;8(3):161-72. doi: 10.1034/j.1600-0501.1997.080302.x

20. Brånemark PI, Engstrand P, Ohrnell LO. Brånemark Novum: a new treatment concept for rehabilitation of the edentulous mandible-preliminary results from a prospective clinical followup study. Clin Implant Dent Relat Res. 1999;1(1):2-16.

21. Schnitman PA. Brånemark implants loaded with fixed provisional prostheses at fixture placement: nine-year follow-up. J Oral Implantol. 1995;21:235-9.

22. Buser $D$, Weber HP, Bragger $U$, Balsiger $C$. Tissue integration of one-stage ITI implants. 3-year results of longitudinal study with hollow-cylinder and hollow-screw implants. Int J Oral Maxillofac Implants.1991;6(4):405-12.

23. Buser $D$, Weber $H P$, Brägger $U$. The treatment of partially edentulous patients with ITI hollow-screw implants: presurgical evaluation and surgical procedures. Int J Oral Maxillofac Implants. 1990;5(2):165-74.

24. Buser D, Sutter E, Weber $H$, Belser $U$, Schroeder A. The IT1 dental implant system: basics, indications, clinical procedures and results. Clin Dent. 1992;5(52):1-23.

25. Ericsson I, Randow K, Glantz PO, Lindhe K. Clinical and radiographical features of submerged and non-submerged titanium implants. Clin Oral Impl Res. 1994;5(3):185-9. doi: 10.1034/j.1600-0501.1994.050310.x

26. Ericsson I, Randow K, Niler K, Petersson AA. Some clinical and radiographical features of submerged and non-submerged titanium implants: a 5-year follow-up study. Clin Oral Impl Res. 1997;8(5):422-6. doi: 10.1034/j.1600-0501.1997.080509.x

27. Becker W, Becker BE, Israelson H, Lucchini M. One-step surgical placement of Brånemark implants: a prospective multicenter clinical study. Int J Oral Maxillofac Implants. 1997;12(4):454-62.

28. Esposito M, Hirsch J, Lekholm U, Thomsen P. Biological factors contributing to failures of osseointegrated implants I. Success criteria and epidemiology. Eur J Oral Sci. 1998;106(1):527-51. doi: 10.1046/j.0909-8836..t01-2-.x

29. Brunski J. Biomaterials and biomechanics in dental implant design. Quintenssence Int. 1988;3(2):87-97.

30. Machado MAS, Fedeli Jr A, Cardoso Jr A, Lustosa AB. Causas da perda de crista óssea periimplantar durante o primeiro ano de função. Implantnews. 2007;4(6):673-6.

Received on: 14/10/2010 Final version resubmitted on: 26/8/2011

Approved on: 15/9/2011 
